\title{
Investigation of the effect of pegbovigrastim on some periparturient immune disorders and performance in Mexican dairy herds
}

\author{
R. Ruiz, ${ }^{* 1}$ L. O. Tedeschi, $†$ and A. Sepúlveda* \\ *Elanco Animal Health, Greenfield, IN 46140 \\ †Department of Animal Science, Texas A\&M University, College Station 77843
}

\begin{abstract}
This study analyzed the efficacy of pegbovigrastim (Imrestor, Elanco Animal Health, Greenfield, IN) on some health and production parameters in lactating dairy cows. Primiparous and multiparous Holsteins from 17 Mexican dairy herds $(\mathrm{n}=10,238)$ were included in this study, which was conducted in 2015. Treated cows $(\mathrm{n}=5,025)$ received Imrestor approximately 7 $\mathrm{d}$ before expected calving and again within $24 \mathrm{~h}$ after calving; control cows $(\mathrm{n}=5,213)$ did not receive a placebo. Clinical mastitis (MAS; 0 to 30 DIM), retained placenta (RP), and clinical metritis (MET; 0 to 21 DIM) occurrences were recorded, as well as the number of medication days, medical treatments needed, and the number of days that milk was discarded due to medication administered for disease. Milk yield was measured from calving until $120 \mathrm{~d}$ in milk. Imrestor reduced the incidence of MAS by $25 \%$, and the odds ratio of having mastitis in the first $30 \mathrm{~d}$ in milk was $35 \%$ greater for control cows than for Imrestor cows. Imrestor treatment reduced the number of medical treatments required for MAS by $6 \%$, and less milk was discarded due to medication for MAS as a result of the Imrestor treatment. The incidence of RP was reduced by $4.15 \%$ with Imrestor and the odds of cows having $\mathrm{RP}$ were $4.6 \%$ greater for control than Imrestor treatments, but they did not differ. The MET incidence was increased by $17.1 \%$ with Imrestor. The use of Imrestor around parturition increased by $5.8 \%$ the odds of inseminating cows during the first $100 \mathrm{~d}$ after calving. Imrestor-treated multiparous cows with MAS produced $2.1 \mathrm{~kg} / \mathrm{d}$ more milk than control cows with MAS during the first $30 \mathrm{~d}$ of their lactation. Imrestor-treated multiparous cows with MET produced $2.3 \mathrm{~kg} / \mathrm{d}$ more milk than MET control cows during the first $120 \mathrm{~d}$ of their lactation. We conclude that Imrestor can help the dairy cow cope with immune periparturient disorders
\end{abstract}

Received September 15, 2016

Accepted December 12, 2016.

${ }^{1}$ Corresponding author: ruiz_rodrigo@elanco.com and can increase the milk yield of dairy cows due to a healthier transition, despite a reported increase in the incidence of MET.

Key words: retained placenta, metritis, mastitis, transition cows, Imrestor

\section{INTRODUCTION}

Successful management of the dairy cow during the Vital 90 Day period (Elanco Animal Health, 2014), defined as $60 \mathrm{~d}$ before and $30 \mathrm{~d}$ after calving, is one of the biggest challenges facing the dairy producer. The metabolic challenge around parturition is such that a dairy cow may enter into a negative energy balance, even before calving and without milk being produced (Grummer, 1995). On the other hand, it is well documented that effects of the parturition itself impair the immune response of the dairy cow (Mallard et al., 2009), and that such immune suppression may start up to $21 \mathrm{~d}$ before calving (Kimura et al., 1999) or only a few days before calving (Jahan et al., 2015). The effect and consequences of the negative energy balance and immune suppression around parturition are shown in Figure 1. Several cows experience reduced feed intake around parturition and impairment of the immune response (Bertoni et al., 2009); therefore, it is key that new approaches are available to dairy producers so management decisions may overcome the potential profit impact due to diseases (Esposito et al., 2014). Approximately $50 \%$ of the dairy cows in the United States suffer from a disease episode in the first 60 DIM, which affects their reproduction efficiency, one of the major components in determining the dairy farm's profitability (Santos et al., 2013). Also, the first $30 \mathrm{~d}$ after calving is the period with the greatest number of animals being culled from the herd (Fetrow et al., 2006).

Colony-stimulating factors (CSF) are a family of glycoprotein cytokines that play a central role in the regulation of hematopoiesis and inflammation. The term CSF was originally derived from the observation that CSF act on progenitor cells to stimulate the formation 


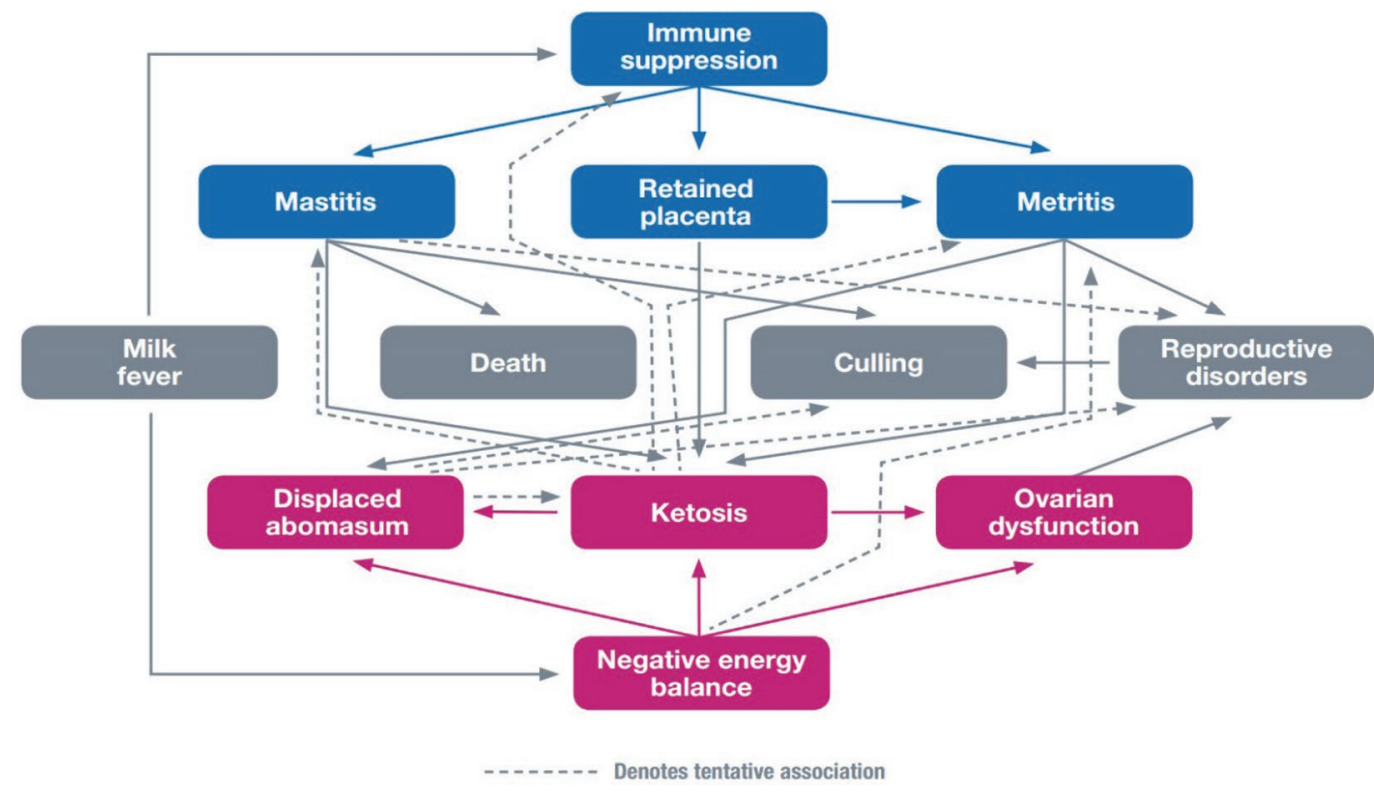

Figure 1. The effect and the consequences of the negative energy balance and immune suppression (Loeffler et al., 1999; Kimura et al., 2002; Sordillo and Streicher, 2002; Huzzey et al., 2007; Duffield et al., 2009). Color version available online.

of colonies comprising mature cells (Kehrli et al., 1991). Early research with CSF showed efficacy in the prevention of clinical mastitis (Nickerson et al., 1989). It was also hypothesized that CSF could be beneficial for supporting the dairy cow around parturition, against respiratory diseases, and uterine diseases (Kehrli et al., 1991). Retained placenta is a disease associated with immune suppression (Gunnink, 1984), and more recently it was correlated with a decrease in neutrophil function (Kimura et al., 2002).

The modification of native proteins by covalent binding to polymers, such as polyethylene glycol, extends the duration of activity of these proteins by increasing their hemodynamic volume, reducing first-pass renal clearance, and reducing their proteolytic degradation (Molineux, 2003). This process, pegylation, has allowed the use of this technology at a commercial level. A recent study showed that cows receiving recombinant bovine granulocyte colony-stimulating factor (G-CSF) covalently bound to polyethylene glycol, administered approximately $6 \mathrm{~d}$ before calving and again within $24 \mathrm{~h}$ postcalving, improved neutrophil function and numbers (Kimura et al., 2014). Such technology was later applied to periparturient dairy cows and heifers, housed in a pen with dirt flooring kept wet to maximize the incidence of naturally occurring clinical mastitis, leading to a reduction in the incidence of clinical mastitis (Hassfurther et al., 2015). However, for field use, long-term studies to determine the efficacy of this drug on health disorders and production of lactating cows are lacking. The purpose of our study was to evaluate the effect of Imrestor (Elanco Animal Health, Greenfield, IN) on immune-related disorders (clinical mastitis, retained placenta, and clinical metritis) during the transition period, and the potential reproductive and productive benefits in Mexican commercial dairy herds.

\section{MATERIALS AND METHODS}

\section{Study Design}

Periparturient multiparous and primiparous Holstein cows from 17 commercial dairy herds $(\mathrm{n}=10,238)$ from 3 different Mexican regions (Chihuahua, Torreon, and Queretaro) were selected for inclusion in the study, which was conducted between April and September 2015. All multiparous and primiparous dairy cows calving in the commitment period were assigned to 2 treatments (Imrestor or control) based on their farm birth ear tag numbers. Before the start of the trial, a coin was flipped to determine Imrestor or control treatment. As a result, even ear tags were assigned as Imrestor treatment, and odd ear tags as control treatment. Imrestor cows $(\mathrm{n}=5,025)$ received Imrestor injections and control cows $(\mathrm{n}=5,213)$ were untreated; control cows did not receive a sham injection. Upon administration of the first Imrestor dose, by farm personnel, a tail wrap was applied to the animal. The tail wrap was removed at the time the second Imrestor dose was applied. Farm personnel were responsible for the evaluation of clinical results. The number of multiparous and primiparous dairy cows that were included in our study was reflec- 
tive of the cows calving at each of the 17 dairy herds. Prior milk yield (MY), if previous lactation standardized production data were available, and parity were recorded for both treatment and control groups. Animals with a normal clinical presentation, based on a physical exam to observe abnormal health conditions at approximately $14 \mathrm{~d}$ before their anticipated calving date, were eligible for inclusion in the study. Animals that were not considered normal or that had been treated with antibiotics or other drugs that might have affected the outcomes of the study within $2 \mathrm{wk}$ before calving at the physical exam were excluded from entering the study. For example, animals with missing teats, animals that were under antibiotic or drug treatments, or animals that had locomotive disorders were excluded. Animals completed the study at $120 \mathrm{~d}$ after calving.

Imrestor is a sterile, injectable formulation of pegbovigrastim (polyethylene glycol-conjugated bovine granulocyte colony-stimulating factor, Elanco Animal Health) in single 2.7-mL dose syringes. Each syringe of Imrestor contains pegbovigrastim $(15 \mathrm{mg})$, L-arginine hydrochloride (94 mg), L-arginine (40 mg), and citric acid monohydrate $(17 \mathrm{mg})$. Imrestor is the result of the pegylation of the natural occurring cytokine, bovine G-CSF, by use of recombinant technology (Hassfurther et al., 2015).

\section{Dosing Regimen}

Utilizing a predicted calving list generated by the trial site herd-management software, animals were observed by the herdsman regularly to identify cows that exhibited clinical signs and were to calve within approximately $7 \mathrm{~d}$. These animals were given a physical exam (recorded on a form) to determine inclusion in the study. For those cows assigned to the Imrestor treatment, the first subcutaneous injection dose was administered approximately $7 \mathrm{~d}$ before expected parturition. The second subcutaneous Imrestor dose was administered within $24 \mathrm{~h}$ after calving (designated as d $0)$. Imrestor syringes were kept in a refrigerator at $4^{\circ} \mathrm{C}$ until used.

\section{Health Disorders}

Clinical Mastitis. Mastitis was measured between 0 and 30 DIM. Clinical mastitis was recognized by visual observation of abnormal milk from a quarter. Observations for clinical mastitis were made at every milking. The clinical scores were recorded on a scale from 1 to 4, where 1 is normal milk with no quarter swelling, 2 is questionable milk with no quarter swelling, 3 is abnormal milk with a swollen or tender quarter, and 4 is acute mastitis with systemic involvement (Smith et al., 1985). A California Mastitis Test was performed on quarters receiving code 2 , if the California Mastitis Test was positive they were classified as mastitic. Systemic involvement included clinical symptoms such as decreased milk production, lack of appetite, dullness, and may include the presence of fever $\left(>39.5^{\circ} \mathrm{C}\right)$. No SCC data were recorded in this study.

Retained Placenta. Retained placenta (RP) is usually recognized when the fetal membranes (placenta) are still visible hanging from the cow's vulva $24 \mathrm{~h}$ after calving. Animals were categorized as having RP if the placenta was not expelled within the $24 \mathrm{~h}$ after calving.

Metritis. Clinical metritis is recognized by an abnormal (smelly and watery) uterine discharge within $21 \mathrm{~d}$ of calving. On palpation per rectum, the uterus appears flaccid, not contracting normally, and fluid filled. Metritis was subdivided into 2 levels of severity (Benzaquen et al., 2007) based on clinical signs and method of treatment. Mild clinical metritis was a metritis without clinical signs apart from the uterine changes and discharges from the vulva, and severe clinical metritis was a metritis with uterine changes, discharges from the vulva, and the presence of clinical signs that may include fever, depression, and lack of appetite. Some farms used thermometers to measure rectal temperature as a diagnostic method to determine whether a cow had a fever. Because it has been reported that a high proportion of cows do not have fever at the time metritis was diagnosed (Benzaquen et al., 2007), indicating that the disease is not always accompanied by a fever, we did not use fever as a cutoff decision for determining the 2 metritis levels.

According to the disease definitions described above, the incidence of mastitis was defined to be from 0 to 30 DIM, and the incidence of metritis was defined to be from 0 to 21 DIM. Any occurrence of mastitis or metritis beyond its defined period was discarded from the health analysis.

\section{Data Collection}

Before the start of the trial, all farm personnel were trained to score clinical mastitis between 0 and 30 DIM, and RP and metritis between 0 and 21 DIM according to the definitions described above. Data collection started in April 2015 and finished by the end of March 2016. Disease scorings were manually captured by farm employees and recorded by field trial monitors into electronic spreadsheets. The medical protocols applied to the disease animals were also registered, as well as the number of treatment days and milk being discarded due to medical treatments received. If an animal was diagnosed cured and no longer medicated, a new medical treatment started if the cow began a new treatment, 
separated from a nondrug period for the same previous disease. Milk yields were captured and stored electronically with the farm's database software, weekly backups were made to avoid data loss, and the information was stored by the sponsor.

\section{Statistical Analysis}

All statistical analyses were conducted with SAS 9.4 (SAS Institute Inc., Cary, NC). The residual (restricted) maximum likelihood was the method used to estimate the covariance parameters. The least squares means with Tukey adjustment for multiple comparisons was used to estimate the fixed effects. Contingency tables (Agresti, 2002) were developed using PROC FREQ, and the $\chi^{2}$ analysis and the Fisher's test were used to assess the homogeneity or independence and the association between row and column variables of a contingency table. Additionally, if the $95 \%$ confidence limit of the odds ratio did not include one, a $P<0.05$ was used to indicate statistical significance.

\section{Health Disorders}

Survival analyses (Hosmer et al., 2008) were used to assess treatment effects on health disorders using PROC LIFETEST. The censoring variable was set to 1 if the event under investigation occurred within the expected time of disease occurrence, and the censoring variable was set to 0 to describe animals that never expressed the disease disorder being investigated within the allowed period or left the experiment before expressing it. The log-rank and Wilcoxon tests were used to assess the treatment effect. The herd variable was used as a control factor (i.e., strata) when the survival analysis was performed within herd. The failure probability plots were evaluated.

\section{Milk Production}

The MY data were analyzed as a repeated measure design using PROC MIXED (Littell et al., 2006). Random factors included regions and herds within regions, and fixed factors included treatment, lactation number, biweekly time, or health disorders (i.e., the occurrence of mastitis, metritis, RP). In a preanalysis, different variance-covariance structures were evaluated. As a result, based on the least Akaike information criterion, the selected statistical model used variance-covariance structure for the random factors and unstructured variance-covariance structure for the repeated measure (i.e., 15-d MY). Because some dairy farms collected daily MY and others collected every other week MY, 15-d MY was computed for all cows that had daily MY records, yielding 1 ( 1 to 15 DIM) to 8 (105 to 120 DIM) 15-d MY. This 15-d MY was the repeated measurement and the subject was cow within treatment, herd, and region. When multiparous cows were analyzed separately, their previous lactation MY was used as a covariate in the repeated measure design analysis.

\section{Reproduction}

The PROC PHREG (Therneau and Grambsch, 2000) was used to perform the Cox proportional hazards regression to determine the relative likelihood of a cow being inseminated within the first 100 DIM. In this analysis, treatment, parity, herd, and month of calving were used as fixed, classificatory factors, and MY of the first 30 DIM was used as a covariate variable.

\section{Lactation Curves}

Equation [1] was used to describe the lactation curve of each cow, and the peak milk was predicted using Equation [2] (Wood, 1967). The PROC NLIN was used to estimate the coefficients for the parameters $a, b$, and $c$ in Equations [1] and [2]. Animals that did not converge were removed from the subsequent analysis. The predicted peak milk (Equation [2]) was analyzed using the PROC MIXED with the same random and fixed factors as described for milk production above. The 305-d lactation MY was predicted using Wood's estimates and Equation [3]. For the prediction of 305-d lactation MY, the coefficients $a, b$, and $c$ (Equation [1]) were obtained for the group rather than individual cows:

$$
\begin{gathered}
\text { MY }=a \times t^{b} \times e^{-c \times t}, \\
\text { Peak milk }=a \times(b / c)^{b} \times e^{-b}, \text { and } \\
\text { Total milk }=\frac{a}{c^{b+1}} \times\left[\Gamma_{(b+1)}-\Gamma_{(b+1.305 \times c)}\right],
\end{gathered}
$$

where $a, b$, and $c$ are parameters of the equation, $e$ is the exponential function (Naperian number), $t$ is DIM, and $\Gamma$ is the incomplete gamma function.

\section{RESULTS}

Figure 2 shows the actual interval between the first dose of Imrestor and the calving date. On average, cows received the first dose $8.3 \mathrm{~d}$ before calving, with a standard deviation of $6.9 \mathrm{~d}$ and a range of 0 to 155 d. Whereas $51.2 \%$ of the animals received the first Imrestor dose within $1 \mathrm{wk}$ before calving, $37 \%$ received it 
DAIRY INDUSTRY TODAY

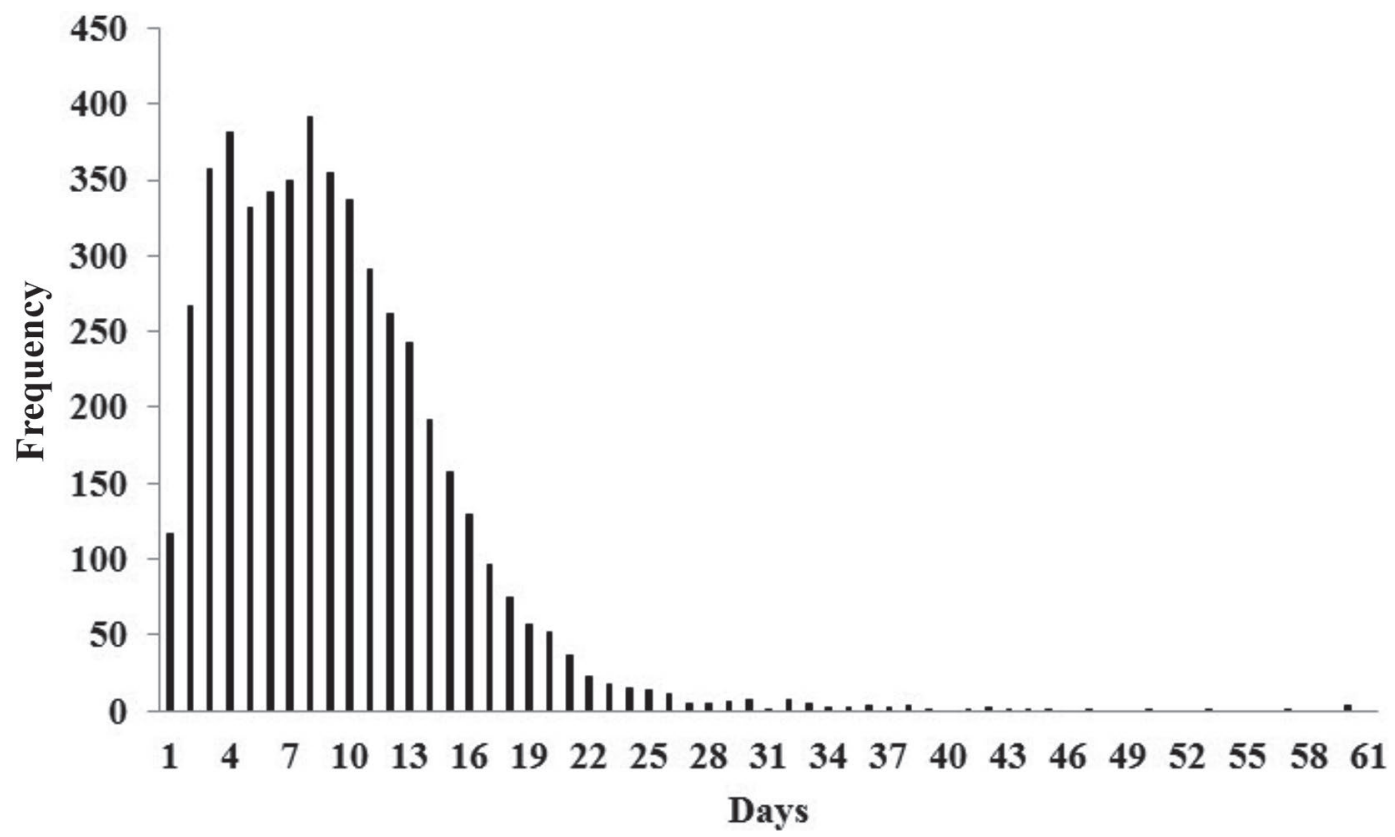

Figure 2. Days from first administration of Imrestor (Elanco Animal Health, Greenfield, IN) to calving (average $=8.3 \mathrm{~d}$, range 0 to $155 \mathrm{~d}$, $\mathrm{SD}=6.9 \mathrm{~d})$.

within the second week before calving, $9.4 \%$ received within the third week before calving, and just $2.4 \%$ beyond the fourth week before calving date. Only the cows that received 2 Imrestor doses were included in this study $(\mathrm{n}=4,953)$, regardless of their first dose administration to calving interval range. Animals that only received 1 Imrestor injection $(\mathrm{n}=72)$ were removed from the study.

\section{Effect of Pegbovigrastim on Mastitis, $R P$, and Metritis}

Table 1 summarizes the statistical analysis for the incidences of mastitis, RP, and metritis. Imrestor reduced the incidence of mastitis by $25 \%$ (Fisher's test $P$-value $=0.0044$; Table 1 ), and the odds ratio of having mastitis in the first 30 DIM were $35 \%$ greater for control cows than for Imrestor cows $(P<0.05$; Table $1)$. The control group had more mastitis scores of 2 $(2.63 \%, 122$ cows vs. $1.62 \%, 71$ cows $)$ and $3(2.11 \%$, 98 cows vs. $1.87 \%, 82$ cows) than the Imrestor-treated group. The incidence of mastitis score 4 was very low for both groups $(0.17 \%, 8$ cows for the control group and $0.21 \%, 9$ cows for Imrestor-treated group). The overall $\chi^{2}$ probability of association was significant at 0.0074. The logistic regression indicated a statistical difference between control and Imrestor cows $(P=$ $0.008)$, with an odds ratio of 1.326 (95\% confidence limit of 1.076 to 1.633), suggesting control cows had a probability of having mastitis (code 2,3 , and 4) that was $33 \%$ greater than Imrestor cows. These results confirmed the results of the mastitis incidence analysis. On average, it took $12 \mathrm{~d}$ for control cows and $10.8 \mathrm{~d}$ for Imrestor cows to exhibit mastitis $(P=0.096$; Table 1$)$. Figure 3 shows the failure plot of the survival analysis for mastitis for the first 30 DIM. Control and Imrestor cows were under mastitis treatment for the same period ( 3.9 vs. $3.7 \mathrm{~d}$, respectively; $P=0.14$, Table 2 ), but the number of mastitis medical treatments differed $(P=$ 0.03 ) between control and Imrestor cows (1.17 vs. 1.1, respectively; Table 2). The number of days that milk was discarded due to mastitis treatment tended to be greater for control than Imrestor cows $(7.6$ vs. 7.2 d, respectively; $P=0.08$; Table 2 ).

The incidence of RP was reduced by $4.15 \%$ with Imrestor and the odds of cows having RP were $4.6 \%$ greater for control than Imrestor treatments, but they did not differ (Fisher's test $P$-value $=0.6071$ and odds ratio $P$-value $>0.05$; Table 1$)$. Multiparous cows treated with Imrestor had a 10\% reduction on the incidence of RP compared with control cows $(P=0.25$; data not shown). Control and Imrestor-treated cows stayed on treatment for RP for the same period ( 3.6 vs. $3.7 \mathrm{~d}$; $P$ $=0.46)$, and we found no difference $(P=0.95)$ between control and Imrestor-treated cows regarding the number of days that milk was discarded for having an RP, averaging 4.73 and $4.74 \mathrm{~d}$, respectively (Table 2 ).

In contrast, the metritis incidence was $17.1 \%$ greater for Imrestor-treated cows compared with control cows (Fisher's test $P$-value $=0.0188$; Table 1$)$, and the odds 


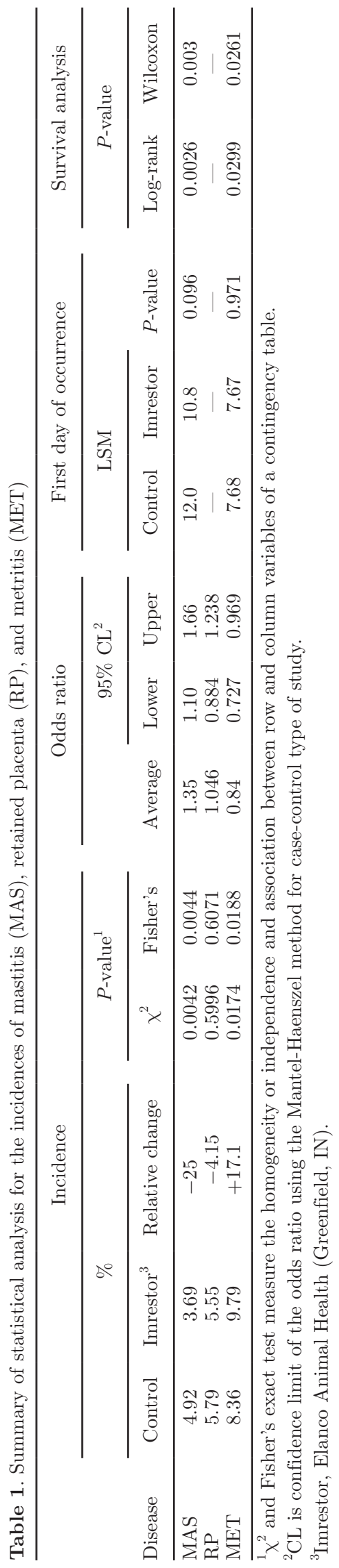

of having metritis was $16 \%$ less for control than Imrestor cows $(P<0.05$; Table 1$)$. Imrestor cows had a greater probability for metritis levels 1 and 2 compared with control cows, but the $\chi^{2}$ test indicated similar probabilities with no association $(P>0.5)$. When compared with control cows, more Imrestor-treated cows had metritis level 1 (243 vs. 227 cows) and 2 (187 vs. 160 cows), but no statistical association between metritis levels and treatments $\left(\chi^{2}=0.3834\right.$ and $P=$ 0.5358 ) was observed. On average, it took $7.7 \mathrm{~d}$ for control and Imrestor cows to exhibit metritis $(P=$ 0.971), and control cows were on treatment for the corresponding disease for $3.31 \mathrm{~d}$, whereas Imrestor cows stayed on treatment for $3.27 \mathrm{~d}(P=0.41$; Table 2$)$. Imrestor cows tended to have less medical treatments compared with control cows, but this difference was not significant (1.11 vs. 1.13 , respectively; $P=0.21$; Table 2 ). For control cows with metritis, $91.1 \%$ received a single treatment and $8.8 \%$ were treated twice (data not shown). Whereas for Imrestor-treated cows, $94.7 \%$ of cows with metritis received a single treatment and only $4.8 \%$ were treated twice (data not shown). We found no difference between control and Imrestor cows regarding the number of days that milk was discarded $(P=0.85$; Table 2), which averaged $4.47 \mathrm{~d}$ for control and $4.49 \mathrm{~d}$ for Imrestor.

During the 120-d trial period, the overall numbers of cows culled were 721 for the control group (51.7\%) and 673 for the Imrestor treatment group (48.3\%; $\chi^{2}$ $=2.673, P=0.976)$. Similarly, we found no statistical differences between control and Imrestor for culling within the first 30 DIM ( $\mathrm{n}=203$ vs. 197, respectively; survival analysis log-rank $P=0.812$ ) or the first 60 DIM (n $=307$ vs. 294, respectively; survival analysis' log-rank $P=0.896)$.

\section{Effect of Pegbovigrastim on MY in Animals with Mastitis, RP, and Metritis}

The MY by parity and disease is summarized in Table 3. The MY of multiparous cows with mastitis that received Imrestor was $2.1 \mathrm{~kg} / \mathrm{d}$ greater than control cows with mastitis during the first 30 DIM $(P=$ 0.06). Additionally, Imrestor increased the production performance of cows that had metritis by $2.1(P=$ $0.04), 2.1(P=0.02)$, and $2.3 \mathrm{~kg} / \mathrm{d}(P=0.01)$ from 0 to 60,0 to 90 , and 0 to 120 DIM, respectively.

\section{Effect of Pegbovigrastim on Days to the First Service}

Treatment (control or Imrestor; $P=0.013$ ), parity (primiparous or multiparous; $P \leq 0.0007$ ), herd ( $\mathrm{n}=$ $17 ; P \leq 0.0001$ ), month of calving (May, June, July, August, September, and October; $P \leq 0.0001$ ), and 


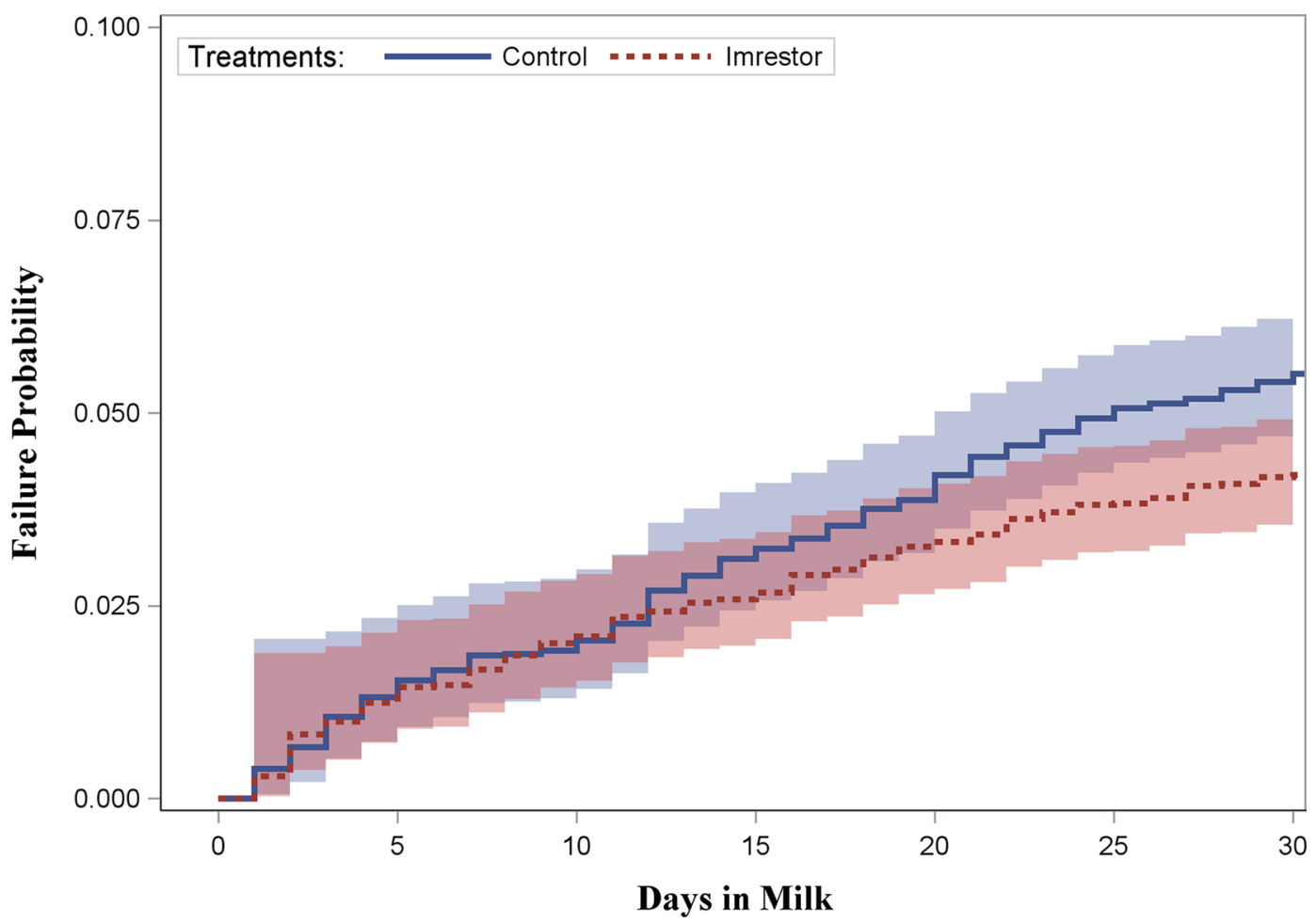

Figure 3. Product-limit failure curves for mastitis incidence stratified by treatment for the first 30 DIM. The solid line is for control cows and the dashed line is for Imrestor (Elanco Animal Health, Greenfield, IN)-treated cows. The shaded region (lighter bands surrounding the lines) limits the $95 \%$ Hall-Wellner bands (lower/reddish band for Imrestor and upper/blueish band to control) and the darker red band is the overlapping region of the bands. Color version available online.

MY for the first $30 \mathrm{~d}(P<0.0001)$ were statistically significant for the Cox proportional hazards statistic for DIM at first service. The hazard ratio of $1.058(P<$ 0.05 ) suggested that Imrestor-treated cows had a 5.8\% greater chance of being inseminated within the first 100 DIM than control cows.

\section{Lactation Curves}

Table 4 shows the peak MY and peak milk day estimated by the Wood's equation for different combinations of parity and diseases. Multiparous cows with mastitis that were treated with Imrestor were estimated to have peaked at $44.2 \mathrm{~kg} / \mathrm{d}$ compared with multiparous control cows with mastitis that were estimated to peak at $41.2 \mathrm{~kg} / \mathrm{d}(P=0.01)$. Multiparous cows that had RP and were treated with Imrestor were estimated to have peaked at d 64 after calving compared with multiparous control cows with RP that were estimated to have peaked at $\mathrm{d} 58.5$ after calving $(P=0.05)$. Similarly, multiparous cows with metritis that were treated with Imrestor were estimated to have peaked at d 66.8 after calving compared with multiparous control cows that were estimated to have peaked at d 59 after calv-

Table 2. Statistical analysis of number of medication days, number of medical treatments, and number of days that milk was discarded due to disease occurrence for control (C) and Imrestor (T; Elanco Animal Health, Greenfield, IN)

\begin{tabular}{|c|c|c|c|c|c|c|c|c|c|c|c|c|}
\hline \multirow{2}{*}{ Item $^{1}$} & \multicolumn{12}{|c|}{ Disease $^{2}$} \\
\hline & \multicolumn{4}{|c|}{ MAS $(\mathrm{n}=441)$} & \multicolumn{4}{|c|}{$\mathrm{RP}(\mathrm{n}=587)$} & \multicolumn{4}{|c|}{$\operatorname{MET}(\mathrm{n}=832)$} \\
\hline Medication days & 3.9 & 3.7 & 0.497 & 0.14 & 3.6 & 3.7 & 0.18 & 0.46 & 3.31 & 3.27 & 0.39 & 0.41 \\
\hline Number of medical treatments & 1.17 & 1.1 & 0.057 & 0.03 & - & - & - & - & 1.13 & 1.11 & 0.063 & 0.21 \\
\hline Number of days milk discarded & 7.6 & 7.2 & 0.67 & 0.08 & 4.73 & 4.74 & 0.68 & 0.95 & 4.47 & 4.49 & 0.42 & 0.85 \\
\hline
\end{tabular}

${ }^{1}$ Medication indicates drugs that were administered to animals to treat diseases.

${ }^{2} \mathrm{MAS}=$ mastitis, $\mathrm{RP}=$ retained placenta, $\mathrm{MET}=$ metritis. 




ing $(P=0.02)$. The predicted 305 -d lactation MY using Wood's (1967) equation for different combinations of parity and disease, for control and Imrestor-treated cows, are depicted in Table 5. Only the RP and MET combinations were analyzed in this study due to a limited sample size.

\section{DISCUSSION}

The time around parturition is the most critical period for any dairy cow. Research had focused heavily on challenge during this time to overcome potential diseases that animals may suffer and that may determine their survival, as well as their entire lactation performance. Management practices and nutritional strategies (Spears and Weiss, 2008; van Knegsel et al., 2013, 2014; Sordillo, 2016) and, most recently, the addition of feed additives (Brandão et al., 2016) are allowing researchers to actively explore how to support the immune system of the dairy cow during this critical period. Despite these efforts, aside from milk fever, most disorders common during the transition period remain as prevalent today as they were in the 1990s (Bradford et al., 2015). A clear need exists for new technologies to help the dairy worker cope with the challenges that cows suffer during the periparturient period.

The first Imrestor dose should ideally be given $7 \mathrm{~d}$ before the anticipated calving date. Gestation length in dairy cattle is affected by genetic, parity, and environmental factors, such as temperature and humidity (Norman et al., 2009). In the current study, the first Imrestor dose was administered according to the farm records. During months of hot weather, farm personnel visited the precalving pens to identify cows that were predicted to calve in 1 or $2 \mathrm{wk}$ based on farm records. For those cows in the 2-wk calving expectancy that had clinical signs of parturition or were judged to calve before the farm record predictions, farm personnel administered the first Imrestor dose. Thus, the variability of the first Imrestor administration to calving was expected to be the one of a regular dairy operation (Figure 2). Whereas $88.2 \%$ of the first Imrestor injections occurred within a 2 -wk window before the actual calving date, $11.8 \%$ of the first Imrestor injections were applied outside the ideal timeline. As the latter group would not necessarily be experiencing the immune suppression around calving time (Jahan et al., 2015), it is important to emphasize the necessity to improve the prediction of the calving date. Based on our field experience obtained during this trial, we recommend observing cows twice weekly for clinical signs of parturition to target the first Imrestor dose according to label recommendations ( $7 \mathrm{~d}$ before expected parturition). Although the registration and incidence levels 
Table 4. Lactation curve peak milk and peak milk day estimated by the Wood's (1967) equation for different diseases and parity ${ }^{1}$

\begin{tabular}{|c|c|c|c|c|c|c|c|c|c|}
\hline \multirow[b]{2}{*}{ Item } & \multirow[b]{2}{*}{$\mathrm{n}$} & \multicolumn{4}{|c|}{ Peak milk yield $(\mathrm{kg} / \mathrm{d})$} & \multicolumn{4}{|c|}{ Peak milk day } \\
\hline & & $\mathrm{C}$ & $\mathrm{T}$ & $\mathrm{SE}$ & $P$-value & $\mathrm{C}$ & $\mathrm{T}$ & $\mathrm{SE}$ & $P$-value \\
\hline \multicolumn{10}{|l|}{ MAS } \\
\hline Multiparous $^{2}$ & 138 & 41.2 & 44.2 & 1.43 & 0.01 & 59.8 & 58.3 & 2.71 & 0.68 \\
\hline Primiparous & 40 & 36.7 & 36.7 & 2.26 & 0.99 & 69.3 & 69.4 & 8.25 & 0.99 \\
\hline \multicolumn{10}{|l|}{ RP } \\
\hline Multiparous $^{2}$ & 158 & 43.3 & 41.7 & 1.55 & 0.10 & 58.5 & 64.0 & 2.87 & 0.05 \\
\hline Primiparous & 44 & 36.8 & 36.2 & 1.33 & 0.72 & 72.6 & 72.8 & 4.53 & 0.96 \\
\hline \multicolumn{10}{|l|}{ MET } \\
\hline Multiparous ${ }^{2}$ & 132 & 43.6 & 43.7 & 1.31 & 0.94 & 59.0 & 66.8 & 4.29 & 0.02 \\
\hline Primiparous & 207 & 34.3 & 34.4 & 1.37 & 0.81 & 73.1 & 69.7 & 3.29 & 0.12 \\
\hline \multicolumn{10}{|l|}{ RP and MET } \\
\hline Multiparous $^{2}$ & 91 & 42.5 & 40.7 & 2.06 & 0.20 & 66.3 & 68.0 & 3.53 & 0.67 \\
\hline Primiparous & 43 & 36.2 & 33.4 & 1.58 & 0.20 & 69.2 & 70.1 & 6.02 & 0.88 \\
\hline
\end{tabular}

${ }^{1} \mathrm{C}=$ control, $\mathrm{T}=$ treatment, Imrestor (Elanco Animal Health Greenfield, IN); MAS = mastitis, $\mathrm{RP}=$ retained placenta, $\mathrm{MET}=$ metritis.

${ }^{2}$ Previous milk yield was used as a covariate, but the previous milk yield and its interaction with treatment were removed if not significant at $P<0.05$.

reported in our study are similar to a recent publication (Santos et al., 2015), it is clear that more emphasis and efforts are needed on record keeping, especially on the incidence of metritis.

A $25 \%$ reduction in the incidence of mastitis due to Imrestor is similar to what has been already reported in a recent study (Hassfurther et al., 2015). In our study, control and Imrestor cows did not significantly differ on the number of treatment days; nonetheless, Imrestor cows had $35 \%$ fewer chances of having a mastitis case in the first 30 DIM and needed $6 \%$ fewer medical treatments if they developed mastitis. The high susceptibility to mastitis in early lactation is well established (Shuster et al., 1996; Oliveira et al., 2013). Reduction of the incidence of mastitis during this criti- cal period will affect the odds of having more mastitis cases throughout the lactation. It has been reported that a cow with a first mastitis case will have a $33 \%$ risk of having a second case and a 13\% risk of having a third mastitis case during her lactation (Rollin et al., 2015). In our study, we focused on mastitis cases only during the first 30 DIM; the effect of Imrestor on the reduction of potential future mastitis cases after this period will need to be explored further. Whereas the timing of mastitis is usually at greater risk on the first week after calving, Figure 3 suggests that control and Imrestor-treated cows started to diverge approximately at d 11 after calving. No data on subclinical mastitis was available in our study as well as bacteriologic evaluations. Thus, limited conclusions can be made

Table 5. Lactation curve predicted 305-d MY using Wood's (1967) equation for different grouping ${ }^{1}$

\begin{tabular}{llllr}
\hline Disease & Parity & Treatment & 305-d MY equation & 305-d MY, kg \\
\hline Mastitis & Primiparous & Control & $11.57 \times \mathrm{t}^{0.3307} \times e^{-0.0051 \times \mathrm{t}}$ & 7,898 \\
& & Imrestor & $13.375 \times \mathrm{t}^{0.264} \times e^{-0.0032 \times \mathrm{t}}$ & 8,787 \\
& Multiparous & Control & $17.054 \times \mathrm{t}^{0.3003} \times e^{-0.0052 \times \mathrm{t}}$ & 10,014 \\
& Imrestor & $18.871 \times \mathrm{t}^{0.2675} \times e^{-0.0041 \times \mathrm{t}}$ & 11,036 \\
Retained placenta & Primiparous & Control & $7.9526 \times \mathrm{t}^{0.4222} \times \mathrm{e}^{-0.0052 \times \mathrm{t}}$ & 8,241 \\
& & Imrestor & $11.373 \times \mathrm{t}^{0.298} \times e^{-0.0034 \times \mathrm{t}}$ & 8,496 \\
& Multiparous & Control & $14.635 \times \mathrm{t}^{0.3488} \times e^{-0.0055 \times \mathrm{t}}$ & 10,341 \\
& & Imrestor & $14.279 \times \mathrm{t}^{0.3363} \times \mathrm{e}^{-0.005 \times \mathrm{t}}$ & 10,202 \\
Metritis & Primiparous & Control & $10.179 \times \mathrm{t}^{0.3311} \times e^{-0.004 \times \mathrm{t}}$ & 8,165 \\
& & Imrestor & $11.436 \times \mathrm{t}^{0.2922} \times e^{-0.0032 \times \mathrm{t}}$ & 8,575 \\
& \multirow{2}{*}{ Multiparous } & Control & $14.369 \times \mathrm{t}^{0.3361} \times e^{-0.0053 \times \mathrm{t}}$ & 9,811 \\
& & Imrestor & $13.205 \times \mathrm{t}^{0.3661} \times e^{-0.0052 \times \mathrm{t}}$ & 10,559 \\
Retained placenta & Primiparous & Control & $8.2401 \times \mathrm{t}^{0.4023} \times e^{-0.0047 \times \mathrm{t}}$ & 8,332 \\
and metritis & Imrestor & $7.3749 \times \mathrm{t}^{0.4182} \times e^{-0.0037 \times \mathrm{t}}$ & 9,330 \\
& \multirow{2}{*}{ Multiparous } & Control & $11.189 \times \mathrm{t}^{0.4218} \times e^{-0.0058 \times \mathrm{t}}$ & 10,600 \\
& & Imrestor & $12.765 \times \mathrm{t}^{0.3624} \times e^{-0.0045 \times \mathrm{t}}$ & 10,989 \\
\hline
\end{tabular}

${ }^{1}$ Control or Imrestor (Elanco Animal Health Greenfield, IN). $\mathrm{t}=$ time (DIM), MY $=$ milk yield, $e$ is the Naperian number (i.e., the exponential function). 
regarding whether animals were incubating pathogens before $\mathrm{d} 11$ and manifesting the disease afterward. Our data show that Imrestor was effective in reducing all defined mastitis scores, though the number of cows with mastitis score 4 were very low. As a mastitis score of 4 would probably be mastitis due to Escherichia coli bacteria, and such mastitis has been discussed to be the main problem around parturition time (Burvenich et al., 2007), it would be interesting to study these findings with a larger mastitis score 4 population. The use of pegbovigrastim was effective in reducing the incidence of mastitis due to gram-positive and -negative bacteria (Hassfurther et al., 2015), and it was shown to reduce by $46.7 \%$ new infections of Staphylococcus aureus compared with controls under experimental conditions (Nickerson et al., 1989). Our study collected no milk SCC data and, to our knowledge, no studies have measured milk SCC of Imrestor-treated cows at the time mastitis was diagnosed. Previous research has shown that the increased numbers of circulating neutrophils in cattle treated with pegbovigrastim are not associated with elevated numbers of somatic cells in healthy mammary glands (Hassfurther et al., 2015). It is expected that cows treated with Imrestor may have a more robust influx of neutrophils into an affected mammary gland at the moment that the pathogen breaches the teat barrier and mammary tissues, but it will need to be further studied.

Antimicrobial drugs used in animal production are under multiple jurisdictions and restrictions (Maron et al., 2013). In the current study, Imrestor reduced the number of days that milk was discarded due to mastitis from 7.6 to $7.2 \mathrm{~d}$, which represents one less milking being discarded due to drug treatment, or a contribution to a reduction in the risk of having antimicrobial drugs in the bulk tank. The reduction of the incidence of mastitis with a reduction of the number of treatments for mastitis while using Imrestor will allow, in conjunction with a more precise scoring of the mastitis, a more specific drug treatment with potential to improve drug utilization at the farm level. Although studies have reported no effects of mastitis on reproduction performance of dairy cows (Fourichon et al., 2000), others have found that mastitis affects the conception rate at the first postpartum AI and the pregnancy rate if a cow developed a mastitis case prior or after her first AI (Santos et al., 2004). The potential effect of Imrestor on fertility due to its mastitis-reduction effects needs to be investigated.

Retained placenta causes significant financial losses, decreases milk yield, decreases body condition, increases the risk for cows to develop MET, decreases fertility, and increases culling rates (Coleman et al., 1985;
Mordak and Stewart, 2015). Though not significant, the overall $4.15 \%$ reduction on the incidence of RP due to Imrestor treatment, as well as the $4.6 \%$ greater odds for control cows to develop RP compared with Imrestor cows, is supported by the etiology of the disease (Kimura et al., 2002) as well as by the Imrestor mode of action (Kimura et al., 2014). Multiparous cows treated with Imrestor were the ones with the greatest RP reduction, but it was not significant. Future research will need to show if manipulating neutrophil function and numbers might be effective in reducing the incidence and risk of developing RP.

In contrast to the 2 previous diseases (mastitis and $\mathrm{RP}$ ), Imrestor treatment resulted in treated animals with a greater incidence of metritis $(17.6 \%)$ and greater odds $(16.4 \%)$ to develop metritis in the first $21 \mathrm{~d}$ after calving. Also, Imrestor cows had greater levels 1 and 2 of metritis scores. Nonetheless, we observed no difference in the first day of metritis, the number of days on treatment due to metritis, the number of days that milk was discarded due to metritis, or the number of medical treatments for metritis. These facts warrant further investigation. The regulation of the inflammatory response in the periparturient cow is quite complex and does not necessarily correlate with the presence of a pathogen (LeBlanc et al., 2011; Esposito et al., 2014). Based on the mode of action of Imrestor, a more robust neutrophil response could lead to more animals exhibiting clinically apparent inflammation. As all periparturient dairy cattle have bacterial contamination of the uterus for 2 to 3 wk after calving (LeBlanc et al., 2011), a rise in neutrophil functions and numbers due to Imrestor administration will likely bias simple clinical methods of diagnosing MET through palpation and visual observations. Visual observations in the field of these animals, diagnosed with metritis by the field workers, allow us to witness robust discharges but not necessarily purulent and fetid discharges. In some of these cases, the discharges were quite clean. Future studies have to follow-up on these field observations, in which a characterization of the polymorphonuclear cells present on the uterus discharges is made. In our study, the diagnosis of metritis was done by visual observations and rectal palpation of the uterus. Complementing these visual observations with the rise of the rectal temperature during 2 consecutive days could better help to predict metritis (Benzaquen et al., 2007). In the same fashion, the utilization of biomarkers such as haptoglobin (Huzzey et al., 2009) could also support the prediction of an inflammatory event and help to prevent the incidence of metritis.

For milk production, Imrestor-treated multiparous cows that developed mastitis within the first 30 DIM 
produced $2.1 \mathrm{~kg} / \mathrm{d}$ more milk than control cows with mastitis $(P=0.06$, Table 3$)$. We did not find differences in the MY of control and Imrestor cows that developed $\mathrm{RP}$ during the first 120 DIM (Table 3); however, it is reported in the literature that the development of RP will affect milk production throughout the lactation (Mordak and Stewart, 2015); future studies need to confirm these findings. Multiparous cows that developed metritis within the first 21 DIM and received Imrestor had $2.3 \mathrm{~kg} / \mathrm{d}$ greater milk production than control cows with metritis during the first $120 \operatorname{DIM}(P=0.01$, Table $3)$. When metritis was early diagnosed, during the first $28 \mathrm{~d}$ after calving, milk production was affected (Rajala and Gröhn, 1998). The severity of the metritis is also a factor to consider when evaluating potential milk production losses throughout the lactation (Huzzey et al., 2007). In our study, the Imrestor cows with metritis showed greater milk production, measured and predicted, regardless of higher disease incidence (Table 1). These findings are in alignment with no increased on medication days, number of medical treatments, and number of days for milk being discarded due to metritis (Table 2), and support the conclusion that robust neutrophil responses that lead to more animals to exhibit early inflammatory responses are not necessarily bad to the animal, as all cows have their uterus contaminated during the first $3 \mathrm{wk}$ after calving. At the beginning of the 1990s, a group of scientists hypothesized about the use of bovine G-CSF to prevent reproductive diseases in cows around parturition time (Kehrli et al., 1991). To our knowledge, the Imrestor milk production benefits on cows that developed metritis are the first documented benefits of the utilization of bovine G-CSF on reproductive diseases, in alignment with this hypothesis.

Overall, Imrestor-treated cows had a $5.8 \%$ greater chance of being inseminated in the first $100 \mathrm{~d}$ after calving compared with control cows. In our study, a mix of techniques (heat detection and timed AI programs) varied among farms and within farms that precluded us from obtaining a robust fertility analysis. Although mastitis (Santos et al., 2004) and uterine diseases (Williams, 2013) have detrimental effects on the dairy cow fertility, follow-up studies will need to be conducted to test the effect of Imrestor on such measurements.

It has been reported that mastitis, RP, and metritis are diseases associated with increasing the risk of culling of lactating dairy cows (Gröhn et al., 1998). In our study, we found no statistical differences in the culling rates of control versus Imrestor-treated cows during the 120-d trial period, and during the first 30 and 60 DIM. As our study was performed during a period shorter than a year, and because relying on farm cull- ing records usually leads to limited or poor conclusions (Fetrow et al., 2006), we believe that additional studies evaluating the effect of Imrestor on cow culling need to be conducted before a conclusion can be drawn.

Lastly, the current study only focused on monitoring some immune-related disorders (mastitis, RP, and metritis) during the first 30 DIM. Although the immune suppression of the dairy cows may start before the energy deficiency (Grummer, 1995; Kimura et al., 1999; Bertoni et al., 2009; Jahan et al., 2015) the interaction between negative energy balance, metabolic and immune diseases, and hypocalcemia is well documented (Kimura et al., 2006; Esposito et al., 2014; Ingvartsen and Moyes, 2015), and the potential benefits of Imrestor on other diseases will need to be further investigated.

\section{CONCLUSIONS}

When Imrestor was administered to dairy cows approximately $7 \mathrm{~d}$ before expected calving and within the first $24 \mathrm{~h}$ after calving, the incidence of mastitis, the risk of having mastitis during the first 30 DIM, as well as the number of medical treatments required for mastitis were reduced. As a result of these observations, less milk was discarded due to drug treatment against mastitis. Similarly, the incidence and risk of developing $\mathrm{RP}$ were also reduced, but likely because of reduced sample size no significance was declared. Under the conditions tested, the clinical signs typically associated with metritis were increased with Imrestor treatment. However, we found no differences on the medication days needed, the number of medical treatments, the number of days that milk needed to be discarded due to Imrestor treatment, and, furthermore, the milk production was increased. Due to the mode of action of Imrestor, the neutrophil increase could lead to more animals exhibiting clinically apparent inflammation. Further investigations characterizing the polymorphonuclear cells presented on the uterus discharges will need to be conducted to better understand these clinical field observations.

\section{ACKNOWLEDGMENTS}

We are grateful for the professional and technical assistance of the following Elanco US employees: Hank Spencer, Margaret Curtis, Peter Canning, Renee Hassfurther, Mike Overton, Darren McGee, and Theo Queis. We extend our appreciation to the Elanco Mexico team: Arturo Martinez, Carlos Parada, Maria Briseño, Sergio D. Gonzalez, Rayel Corral, Nailea Grijalva, and Luis Ignacio Hernandez for their help at the field observation of cows and data collection. A special recognition 
is also extended to the farmers who were willing to be part of this study, and the farm employees who helped to collect additional data.

\section{REFERENCES}

Agresti, A. 2002. Categorical Data Analysis. 2nd. ed. John Wiley \& Sons, New York, NY.

Benzaquen, M. E., C. A. Risco, L. F. Archbald, P. Melendez, M. J. Thatcher, and W. W. Thatcher. 2007. Rectal temperature, calving-related factors, and the incidence of puerperal metritis in postpartum dairy cows. J. Dairy Sci. 90:2804-2814.

Bertoni, G., E. Trevisi, and R. Lombardelli. 2009. Some new aspects of nutrition, health conditions and fertility of intensively reared dairy cows. Ital. J. Anim. Sci. 8:491-518.

Bradford, B. J., K. Yuan, J. Farney, L. Mamedova, and A. Carpenter. 2015. Invited review: Inflammation during the transition to lactation: New adventures with an old flame. J. Dairy Sci. 98:66316650.

Brandão, A. P., R. F. Cooke, F. N. Corrá, M. B. Piccolo, R. Gennari, T. Leiva, and J. L. M. Vasconcelos. 2016. Physiologic, health, and production responses of dairy cows supplemented with an immunomodulatory feed ingredient during the transition period. J. Dairy Sci. 99:5562-5572.

Burvenich, C., D. D. Bannerman, J. Lippolis, L. Peelman, B. Nonnecke, M. Kehrli, and M. Paape. 2007. Cumulative physiological events influence the inflammatory response of the bovine udder to Escherichia coli infections during the transition period. J. Dairy Sci. 90:E39-E54.

Coleman, D. A., W. V. Thayne, and R. A. Dailey. 1985. Factors affecting reproductive performance of dairy cows. J. Dairy Sci. 68:1793-1803.

Duffield, T. F., K. Lissemore, B. McBride, and K. Leslie. 2009. Impact of hyperketonemia in early lactation dairy cows on health and production. J. Dairy Sci. 92:571-580.

Elanco Animal Health. 2014. The Vital 90 Days. Elanco Animal Health, Greenfield, IN.

Esposito, G., P. C. Irons, E. C. Webb, and A. Chapwanya. 2014. Interactions between negative energy balance, metabolic diseases, uterine health and immune response in transition dairy cows. Anim. Reprod. Sci. 144:60-71.

Fetrow, J., K. Nordlund, and H. Norman. 2006. Invited review: Culling: Nomenclature, definitions, and recommendations. J. Dairy Sci. 89:1896-1905.

Fourichon, C., H. Seegers, and X. Malher. 2000. Effect of disease on reproduction in the dairy cow: a meta-analysis. Theriogenology 53:1729-1759.

Gröhn, Y. T., S. W. Eicker, V. Ducrocq, and J. A. Hertl. 1998. Effect of diseases on the culling of Holstein dairy cows in New York State. J. Dairy Sci. 81:966-978.

Grummer, R. R. 1995. Impact of changes in organic nutrient metabolism on feeding the transition dairy cow. J. Anim. Sci. 73:28202833.

Gunnink, J. W. 1984. Pre-partum leucocytic activity and retained placenta. Vet. Q. 6:52-54

Hassfurther, R. L., T. N. TerHune, and P. Canning. 2015. Efficacy of polyethylene glycol-conjugated bovine granulocyte colony-stimulating factor for reducing the incidence of naturally occurring clinical mastitis in periparturient dairy cows and heifers. Am. J. Vet. Res. 76:231-238.

Hosmer, D. W., S. Lemeshow, and S. May. 2008. Applied Survival Analysis: Regression Modeling of Time-To-Event Data. 2nd. ed. Wiley Series in Probability and Statistics. Wiley-Interscience, Hoboken, N.J.

Huzzey, J. M., D. Veira, D. Weary, and M. Von Keyserlingk. 2007. Prepartum behavior and dry matter intake identify dairy cows at risk for metritis. J. Dairy Sci. 90:3220-3233.
Huzzey, J. M., T. F. Duffield, S. J. LeBlanc, D. M. Veira, D. M. Weary and M. A. G. von Keyserlingk. 2009. Short communication: Haptoglobin as an early indicator of metritis. J. Dairy Sci. 92:621-625.

Ingvartsen, K. L., and K. M. Moyes. 2015. Factors contributing to immunosuppression in the dairy cow during the periparturient period. Jpn. J. Vet. Res. 63(Supplement 1):S15-S24.

Jahan, N., A. Minuti, and E. Trevisi. 2015. Assessment of immune response in periparturient dairy cows using ex vivo whole blood stimulation assay with lipopolysaccharides and carrageenan skin test. Vet. Immunol. Immunopathol. 165:119-126.

Kehrli, M. E., J. S. Cullor, and S. C. Nickerson. 1991. lrnmunobiology of hematopoietic colony-stimulating factors: Potential application to disease prevention in the bovine. J. Dairy Sci. 74:4399-4412.

Kimura, K., J. P. Goff, P. Canning, C. Wang, and J. A. Roth. 2014 Effect of recombinant bovine granulocyte colony-stimulating factor covalently bound to polyethylene glycol injection on neutrophil number and function in periparturient dairy cows. J. Dairy Sci. 97:4842-4851.

Kimura, K., J. P. Goff, and M. E. Kehrli. 1999. Effects of the presence of the mammary gland on expression of neutrophil adhesion molecules and myeloperoxidase activity in periparturient dairy cows. J. Dairy Sci. 82:2385-2392.

Kimura, K., J. P. Goff, M. E. Kehrli, and T. A. Reinhardt. 2002. Decreased neutrophil function as a cause of retained placenta in dairy cattle. J. Dairy Sci. 85:544-550.

Kimura, K., T. A. Reinhardt, and J. P. Goff. 2006. Parturition and hypocalcemia blunts calcium signals in immune cells of dairy cattle. J. Dairy Sci. 89:2588-2595.

LeBlanc, S. J., T. Osawa, and J. Dubuc. 2011. Reproductive tract defense and disease in postpartum dairy cows. Theriogenology $76: 1610-1618$

Littell, R. C., G. A. Milliken, W. W. Stroup, R. D. Wolfinger, and O. Schabenberger. 2006. SAS for Mixed Models. 2nd ed. SAS Institute, Cary, NC

Loeffler, S. H., M. J. de Vries, and Y. H. Schukken. 1999. The effects of time of disease occurrence, milk yield, and body condition on fertility of dairy cows. J. Dairy Sci. 82:2589-2604.

Mallard, B. A., B. W. McBride, M. E. Kehrli, and P. M. Coussens, 2009. Bovine immunophysiology and genetics: A review of the research and career of Jeanne L. Burton. Vet. Immunol. Immunopathol. 128:96-103.

Maron, D. F., T. J. Smith, and K. E. Nachman. 2013. Restrictions on antimicrobial use in food animal production: an international regulatory and economic survey. Global. Health 9:48.

Molineux, G. 2003. Pegylation: Engineering improved biopharmaceuticals for oncology. Pharmacotherapy $23: 3 \mathrm{~S}-8 \mathrm{~S}$.

Mordak, R., and P. A. Stewart. 2015. Periparturient stress and immune suppression as a potential cause of retained placenta in highly productive dairy cows: Examples of prevention. Acta Vet. Scand. 57:84.

Nickerson, S. C., W. E. Owens, and J. L. Watts. 1989. Effects of recombinant granulocyte colony-stimulating factor on Staphylococcus aureus mastitis in lactating dairy cows. J. Dairy Sci. 72:3286-3294.

Norman, H. D., J. Wright, M. Kuhn, S. Hubbard, J. Cole, and P. VanRaden. 2009. Genetic and environmental factors that affect gestation length in dairy cattle. J. Dairy Sci. 92:2259-2269.

Oliveira, L., C. Hulland, and P. L. Ruegg. 2013. Characterization of clinical mastitis occurring in cows on 50 large dairy herds in Wisconsin. J. Dairy Sci. 96:7538-7549.

Rajala, P. J., and Y. Gröhn. 1998. Effects of dystocia, retained placenta, and metritis on milk yield in dairy cows. J. Dairy Sci $81: 3172-3181$.

Rollin, E., K. Dhuyvetter, and M. Overton. 2015. The cost of clinical mastitis in the first 30 days of lactation: An economic modeling tool. Prev. Vet. Med. 122:257-264.

Santos, J., R. Bisinotto, E. Ribeiro, N. Martinez, and F. Lima. 2013. Role of animal health on reproduction of dairy cows. Pages 32-48 in Proc. 2013 Dairy Cattle Reproduction Council Conference, Indianapolis, IN. Dairy Cattle Reproduction Council, Dublin, OH. 
Santos, J. E. P., P. Pinedo, G. M. Schuenemann, R. C. Bicalho, R. C. Chebel, K. N. A. Galvao, R. O. Gilbert, S. Rodriguez-Zas, G. J. M. Rosa, C. Seabury, J. Fetrow, and W. W. Thatcher. 2015. Improving fertility of dairy cows through genomic selection. Pages 3-9 in Dairy Cattle Reproduction Council Proceedings, Buffalo, NY. Dairy Cattle Reproduction Council, Dublin, OH.

Santos, J. E. P., R. L. A. Cerri, M. A. Ballou, G. E. Higginbotham, and J. H. Kirk. 2004. Effect of timing of first clinical mastitis occurrence on lactational and reproductive performance of Holstein dairy cows. Anim. Reprod. Sci. 80:31-45.

Shuster, D. E., E. Lee, and M. Kehrli Jr.. 1996. Bacterial growth, inflammatory cytokine production, and neutrophil recruitment during coliform mastitis in cows within ten days after calving, compared with cows at midlactation. Am. J. Vet. Res. 57:1569-1575.

Smith, K. L., D. A. Todhunter, and P. S. Schoenberger. 1985. Environmental mastitis: Cause, prevalence, prevention. J. Dairy Sci. 68:1531-1553.

Sordillo, L. M. 2016. Nutritional strategies to optimize dairy cattle immunity. J. Dairy Sci. 99:4967-4982.

Sordillo, L. M., and K. L. Streicher. 2002. Mammary gland immunity and mastitis susceptibility. J. Mammary Gland Biol. Neoplasia $7: 135-146$
Spears, J. W., and W. P. Weiss. 2008. Role of antioxidants and trace elements in health and immunity of transition dairy cows. Vet. J. 176:70-76.

Therneau, T. M., and P. M. Grambsch. 2000. Modeling Survival Data: Extending the Cox Model. Statistics for Biology and Health. Springer, New York, NY.

van Knegsel, A. T., H. M. Hammon, U. Bernabucci, G. Bertoni, R. M. Bruckmaier, R. M. Goselink, J. J. Gross, B. Kuhla, C. C. Metges, and H. K. Parmentier. 2014. Metabolic adaptation during early lactation: key to cow health, longevity and a sustainable dairy production chain. CAB Rev. Perspect. Agric. Vet. Sci. Nutr. Nat. Resour. 9:15.

van Knegsel, A. T. S. G. van der Drift, J. Čermáková, and B. Kemp. 2013. Effects of shortening the dry period of dairy cows on milk production, energy balance, health, and fertility: A systematic review. Vet. J. 198:707-713.

Williams, E. J. 2013. Drivers of post-partum uterine disease in dairy cattle. Reprod. Domest. Anim. 48(Suppl. 1):53-58.

Wood, P. D. P. 1967. Algebraic model of the lactation curve in cattle. Nature 216:164-165. 